\title{
Stendhal syndrome: a clinical and historical overview
}

\author{
Síndrome de Stendhal: una revisión histórica y clínica \\ Leonardo Palacios-Sánchez Juan Sebastián Botero-Meneses Rocio Plazas Pachón² Laura Bibiana \\ Piñeros Hernández² Juanita del Pilar Triana-Melo² Santiago Ramírez-Rodriguez²
}

\begin{abstract}
It could be argued that one of the few unifying qualities all human beings share is the ability to appreciate beauty. While the object of beauty may change from one person to another, the awe and the thrill experienced by an enthralled beholder remains the same. Sometimes, this experience can be so overwhelming it can bring someone to the edge of existence. A very rare condition, known as aesthetic syndrome and, more commonly, Stendhal syndrome, entails a clinical phenomenon in which the presence of a beautiful piece of work or architecture causes dysautonomic symptoms such as tachycardia, diaphoresis, chest pains and loss of consciousness. We present an historical and clinical review of this condition.
\end{abstract}

Keywords: Stendhal syndrome; Psychiatry; Neurology; history.

\section{RESUMO}

Podría decirse que una de las pocas cualidades comunes a todos los seres humanos es la capacidad de apreciar la belleza. Si bien, es cierto que el objeto considerado como bello cambia de una persona a otra, la admiración y profunda emoción que experimenta un espectador en trance, es la misma. En ocasiones, esta experiencia puede llevar una persona hasta el borde mismo de la existencia. Una condición muy rara, conocida como síndrome estético, y en algunos casos, síndrome de Stendhal, comprende un cuadro clínico en el que la presencia de una magnífica y bella pieza de arte o arquitectura, produce síntomas disautonómicos como taquicardia, diaforesis, dolor torácico y pérdida de la consciencia. Presentamos aquí una revisión clínica e histórica de esta condición.

Palabras-clave: síndrome Stendhal; Psiquiatría; Neurología; historia.

Stendhal syndrome is a condition characterized by the confluence of different symptoms, both physical and mental, when in the presence of a beautiful piece of art. The term was coined in 1989 by Italian psychiatrist, Graziella Magherini, in honor of the nineteenth century romantic writer Marie-Henri Beyle, widely known by his pseudonym "Stendhal",2. This article reviews the history and particular characteristics of the syndrome.

\section{HISTORICAL CONTEXT}

Marie-Henri Beyle (1783-1842) was born in Grenoble, France (Figure). He was a man of extreme sensibility and was, indeed, a hopeless romantic. Both of these features of his character would transcend into all aspects of his life and would be the foundations for his actions, his work and the way he saw the world. In 1800, he started his military career in the Napoleonic navy as a lieutenant and, in the same year, he was tasked with various military activities in Italy, a country he came to love deeply, even to the point of regarding himself as a "Milanese". Two years later, he left the navy and took to public office, working in various executive affairs for the Napoleonic Empire in Germany, Austria and Russia.

After the Fontainebleau treaty was signed in 1814, in lieu of Napoleon's defeat, Beyle returned to Italy and, shortly after settling in Milan, set off on a grand tour of the entire country. During this time, his love for Italy, it's land, it's people and their customs grew with every passing day and in 1817 he published Rome, Naples et Florence, the first work in which he would use the name "Stendhal".

Beyle chose his pseudonym after the city of Stendal, the capital of the Altmark region in the German state of SaxonyAnhalt, set on the eastern border of the French empire during the Germanic expansion of the middle ages.

1 Universidad del Rosario, Department of Neuroscience, Bogotá, Colombia;

${ }^{2}$ Universidad del Rosario, Bogotá, Colombia.

Correspondence: Leonardo Palacios-Sánchez; Universidad del Rosario; Cr. 24 \# 63c-74; Bogotá Colombia, 11001000; E-mail: leonardo.palacios@urosario.edu.co Conflict of interest: There is no conflict of interest to declare.

Received 24 July 2017; Received in final form 02 November 2017; Accepted 13 November 2017. 


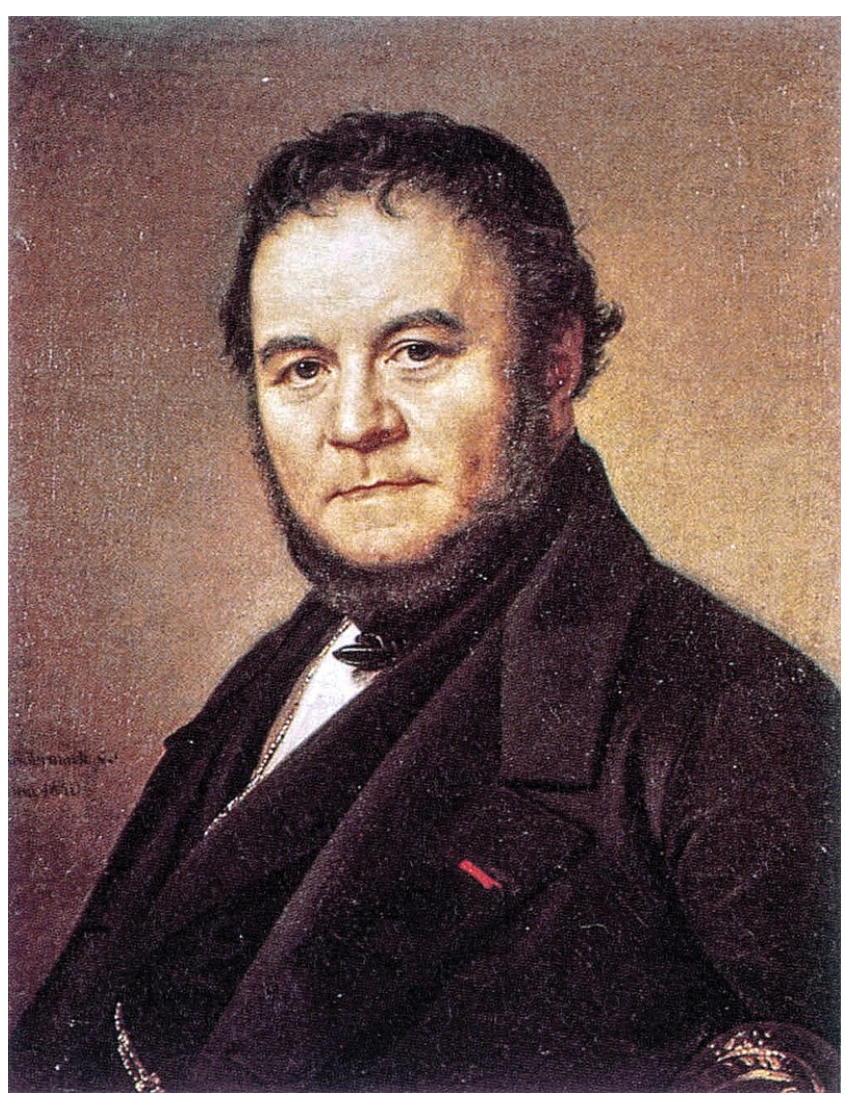

Figure. Marie-Henri Beyle, a.k.a. Stendhal, 1840, By Olof Johan Södermark.

Over the course of his life, Beyle traveled far across the lands, touring France, visiting England, Spain and, on several occasions, Germany. He would not return to his beloved Italy until 1831, when he was appointed head of the consular office Civitavecchia for a four-year period. He continued to journey across the Italian peninsula for three more years until he decided to return to his homeland in France. He died in Paris on the March 23, 1842, from a stroke ${ }^{3}$.

\section{THE CHARACTERISTICS OF STENDHAL SYNDROME}

The syndrome was described by Dr. Graziella Magherini, based on 106 cases of foreign (vis-a-vis non-Italian) patients seen at the Santa Maria Nuova Hospital in Florence. These patients exhibited clinical symptoms that were consistent with Stendhal's writings after he visited the Basilica di Santa Croce in the same city, thus the condition is also referred to as the "Florentine syndrome". However, a similar phenomenon was described when people visited other cities 4 coining the "Paris syndrome", described in 1986 by Japanese psychiatrist Hiroaki Ota, who observed several people who, after visiting Paris, presented with dizziness, tachycardia, heart palpitations, shortness of breath and psychiatric symptoms ranging from hallucinations, both visual and auditory, to paranoid persecutory delusion and depersonalization disorders. According to Dr. Ota's findings, this clinical presentation could have been caused by the major impact the traveler experiences when facing a significantly different culture and way of life than his/her own ${ }^{5}$.

Another ailment related to the encounter with a different world was observed by Dr. Bar-El and his coworkers ${ }^{1}$. The condition, known as "Jerusalem syndrome" has remarkably similar characteristics to those of Stendhal syndrome, in addition to the presence of messianic ideas and a general delusion of grandeur upon visiting a city that is considered, as a whole, as the "holy land" by three of the world's most-followed, influential and powerful religions. Other cities and landmarks, including Venice, Rome and Istanbul have been linked to these aesthetic syndromes by various authors ${ }^{6}$.

It would appear, that Stendhal syndrome is more commonly suffered by Europeans than North Americans, Asians or Latin-Americans?

History tells us of many famous people who may have experienced symptoms consistent with Stendhal syndrome. Among these, psychoanalyst Sigmund Freud wrote about severe feelings of alienation and depersonalization upon visiting the Acropolis of Athens ${ }^{6}$, and writer Fyodor Dostoevsky experienced severe paralysis, and absence when faced with Hans Holbein's Le Christ mort au tombeau in Basel, Switzerland ${ }^{4,8}$.

\section{DEFINITION}

On January 22, 1817, while visiting Naples, Stendhal entered the Santa Croce chapel in Florence. In this chapel, covered with marvelous frescoes by Giotto di Bondone, superb paintings by Baldassare Franceschini, known as "Il Volterrano"; a temple that houses the tombs of Niccolo Machiavelli, Galileo Galilei and Michelangelo Buonarroti, Stendhal experienced a life-changing event. As a monk opened the gates, the French poet knelt on a prayer bench, and leaned his head back in awe. About this moment, he wrote: "I had reached that point of emotion that meets the heavenly sensations given by the Fine Arts and passionate feelings. Leaving Santa Croce, I had an irregular heartbeat, life was ebbing out of me, I walked with the fear of falling"'.

This was a sublime ecstasy, during which Beyle felt "close to heaven" and experienced severe tachycardia and gait dyspraxia $^{2}$. Many years later in 1989, Dr. Magherini published her findings on the aforementioned 106 patients, during a 20 -year-long observation. After various visits to Florence, it's museums and galleries, most of the patients experienced dizziness, heart palpitations, hallucinations, disorientation, depersonalization and profound exhaustion. It should be mentioned that those whose visits were arranged by a travel agency, which involved several trips in a short period of time, presented with worse symptoms.

The etiology of the syndrome has been regarded overall as a product of the experience of finding oneself in a city or a 
building that allows the visitor to behold wondrous works of art, the greatness of the past and its historical perspective $e^{2,3}$.

In each individual case, Dr. Magherini observed some of the following common characteristics: the clinical onset of symptoms was sudden, and their duration spanned from two to eight days. The most frequent manifestations were: chest pains, palpitations, diaphoresis, asthenia and anxiety. Some of the victims of the most acute cases attempted to damage or destroy the artworks that elicited their discomfort ${ }^{9}$.

After collecting these observations, Dr. Magherini proposed three different clinical presentations of the condition. Sixty-six percent of the patients reported mainly neuropsychiatric symptoms, 29\% exhibited severe mood disorders and $5 \%$ presented with panic attacks and dysautonomia symptoms, including cardiovascular complaints, resembling acute myocardial infarction or acute abdominal pain, caused by peptic ulcer, and/or intense acid reflux and dyspepsia ${ }^{2,4,6,8,9}$.

Lastly, Dr. Magherini proposed yet another clinical variation of the condition, a very specific one regarding an encounter with Michelangelo's masterful sculpture of the biblical hero, David. This famous sculpture, housed in the Galleria dell'Accademia in Florence, gave rise to deep feelings of sexual pleasure, aesthetic pleasantness as well as, interestingly, causing profound envy due to its representation of physical perfection. These mixed feelings were bewildering for many tourists, causing serious sexual dysfunctions, and thus, Dr. Magherini refers to the phenomenon as David's syndrome ${ }^{6}$. She has been quoted as describing Michelangelo's David as "a fusion of libido and art”.

It is noteworthy to say that aesthetic syndromes are not caused only by manmade works of art. In the presence of the magnificent and almighty presence of nature, a critical physiological response is produced, closely resembling syncope, or sexual climax ${ }^{9}$.

\section{TREATMENT AND PROGNOSIS}

Specific treatment for this condition, as far as the evidence shows, does not go further than preventing major injury following syncopal activity, or ruling out major associated complications or comorbidities, as well as important differential diagnoses ${ }^{8,9}$. Arias's work showed brain activity in several regions of the brain involved in consciousness, emotion processing, social interaction and memory in Stendhal syndrome, that do not appear to be particularly morbid ${ }^{8}$. Additionally, several triggering risk factors have been identified and will be discussed.

As far as the prognosis for this condition goes, one can assume that the person inflicted by Stendhal syndrome will experience these symptoms many times in his or her lifetime while contemplating other works of art elsewhere. The question remains whether recollection of the precipitating piece of art elicits a new onset of symptoms.

\section{Risk factors}

As it is true for most human ailments, there are risk factors for Stendhal syndrome. Educational level, marital status, age, and stress over traveling are among them. This is why it is highly recommended for travelers to be well rested, and adequately hydrated and fed. Sun protection is also strongly suggested.

On the other hand, living alone, reaching the end of a journey and a religious upbringing are also major risk factors. The latter is interesting to ponder. The history of religion, whichever this may be, is deeply linked to art; it is known to many that most of the great masterpieces of art from the Middle Age or the renaissance were attempts to represent icons, epic feats and events written in holy texts. Miraculous circumstances and apparitions, the imagery and representation of ethereal beings of great beauty and power, are the ends to which art is a means. In the same way, a number of art pieces were made at the request of the church and the clergy to cover the walls of cathedrals, mosques and synagogues.

Finally, we can safely presume that the end of a journey to a city of vast cultural heritage produces a profound sense of sadness and melancholy in the traveler, who is now forced to return to his city of origin, which may not compare with the gorgeous works of art in the city that has been visited and, without question, the end of the sweet pleasure of vacationing produces the onset of very distressing symptoms ${ }^{9}$.

\section{FINAL COMMENTS}

Stendhal syndrome is a polymorphic entity from a clinical standpoint and, therefore, it must be approached in an individual manner.

Some conditions must be considered as differential diagnoses, such as ecstatic epilepsy, a condition recognized by the onset of mood altering crises in patients, with sudden changes between pleasure and discomfort, often religious in background ${ }^{10}$.

Guerrero and his coworkers ${ }^{6}$ designed a survey that they applied to a number of neurologists who attended a neuro-history course, hosted by the Spanish Society of Neurology, which took place in Italy in February 2008. The survey sought to assess the presence of Stendhal syndrome symptoms during the period of the course. Forty-eight surveys were applied, in which $17 \%$ of the doctors presented with melancholy while $13 \%$ reported feelings of anxiety. Eighty-three percent of the visiting physicians acknowledged significant aesthetic pleasure, $62 \%$ showed excitement, 33\% were euphoric. Ten percent reported perceptual disorders, $4 \%$ a deep sense of guilt and $6 \%$ experienced discomforting somatic symptoms ${ }^{6}$.

Stendhal syndrome points out a possible relationship between tourist travel and famous art-filled cities like Florence, Paris, Athens, Tokyo, Rome, and others. This is a manifestation of the link between emotion and knowledge, 
which lies in the deepest spaces of the mind. When the traveler beholds grand works of art, a displacement and detachment from their familiar environment takes place, which determines the onset of symptoms and their eventual treatment. Affected patients are overwhelmed by beauty and are forced to remove themselves from the experience, due to their inability to tolerate the passionate connection of art with man.

The name of Stendhal syndrome is a trademark for beauty through painful reconstruction, of utopic moments brought about by art. Quoting Stendhal himself: "Beauty is no other thing than a promise of happiness"6.

\section{References}

1. Bar-El Y, Durst R, Katz G, Zislin J, Strauss Z, Knobler HY Jerusalem syndrome. Br J Psych. 2000;176(1):86-90. https://doi.org/10.1192/bjp.176.1.86

2. Ledermann W. Memorias literarias de la difteria: Mark Twain, W.G. Sebald y el sindrome de Stendhal . Rev Chilena Infectol. 2013;30(1):98-102. https://doi.org/10.4067/S0716-10182013000100018

3. Bamforth I. Stendhal's syndrome. Br J Gen Pract. 2010;60(581):945-6. https://doi.org/10.3399/bjgp10X544780

4. Picard D, Robinson M. Emotion in motion: tourism, affect and transformation. New York: Routledge; 2016.

5. Nicholson TRJ, Pariante C, McLoughlin D. Stendhal syndrome: a case of cultural overload. BMJ Case Reports. 2009;2009:bcr06.2008.0317. https://doi.org/10.1136/bcr.06.2008.0317
6. Teive H, Munhoz R, Cardoso F. Proust, neurology and Stendhal's syndrome. Eur Neurol. 2014;71(5-6):296-8. https://doi.org/10.1159/000357562

7. Arias M. Neurología del éxtasis y fenómenos aledaños: epilepsia extática, orgásmica y musicogénica. Síndrome de Stendhal. Fenómenos autoscópicos. Neurología. 2016. http://dx.doi.org/10.1016/j.nrl.2016.04.010

8. Juarez, EA. La belleza como promesse du bonheur: algunas notas sobre su origen en Stendhal. En-clav Pen. 2014;8(15):123-46.

9. Amâncio EJ. Dostoevsky and Stendhal's syndrome. Arq Neuropsiquiatr. 2005;63(4):1099-103. https://doi.org/10.1590/S0004-282X2005000600034

10. Guerrero AL, Barcelló Roselló A, Ezpeleta D. Síndrome de Stendhal: origen, naturaleza y presentación en un grupo de neurólogos. Neurología. 2010;25(6):349-56. https://doi.org/10.1016/j.nrl.2010.02.004 